\title{
THE PROTECTIVE EFFECT OF ZINC AND MAGNESIUM AGAINST SUBCHRONIC CADMIUM TOXICITY IN WISTAR RATS (BIOCHEMICAL AND NEUROBEHAVIORAL EFFECTS)
}

\author{
MOHAMED KOUADRIA, SAMIR DJEMLI*, ABDELKRIM TAHRAOUI
}

Applied Neuroendocrinology Laboratory, Department of Biology, Faculty of Sciences, University Badji Mokhtar, Sidi Amar, Annaba, Algeria. Email: s_djemli@yahoo.fr

Received: 03 September 2018, Revised and Accepted: 08 April 2019

\section{ABSTRACT}

Objective: The present study shows the beneficial effect of zinc $10 \mathrm{mg} / \mathrm{kg}+$ magnesium $10 \mathrm{mg} / \mathrm{kg}$ against cadmium poisoning at a dose of $15 \mathrm{mg} / \mathrm{kg}$ on biochemical parameters and neurobehavioral functions in Wistar rats during a period of 45 days.

Methods: The experiment was carried out on 20 Wistar rats, weighing 180-232 g for an initial weight before starting treatment with cadmium. The rats are grouped in cages at a rate of 5 in groups: Group (1) control was supplied only with water. Group (2) contaminated with cadmium (Cd): Water plus oral administration cadmium dose $15 \mathrm{mg} / \mathrm{kg} / \mathrm{l}$. Group (3) contaminated with (Cd) dose $15 \mathrm{mg} / \mathrm{kg} / \mathrm{l}$ in water plus magnesium (Mg) dose $10 \mathrm{mg} / \mathrm{kg} / \mathrm{l}$ oral administration. Group (4) contaminated with (Cd) dose $15 \mathrm{mg} / \mathrm{kg} / \mathrm{l}$ in water plus zinc (Zn) dose $10 \mathrm{mg} / \mathrm{kg} / \mathrm{l}$ oral administration.

Results: The rats exposure to cadmium showed a very highly significant decrease in body weight of cadmium-contaminated rats $(\mathrm{p}<0.001)$ compared with the control group. Regarding the biochemical parameters, there was a very highly significant increase ( $<<0.001)$ in the cadmium group blood glucose level compared to the control group, a highly significant increase $(p<0.01)$ in the group urea level. Cadmium compared to the control, a very highly significant increase $(\mathrm{p}<0.001)$ in the creatinine level of the cadmium lot compared to the control, a very highly significant increase ( $\mathrm{p}<0.001)$ of transaminases (glutamic oxaloacetic transaminase and glutamic-pyruvic transaminase) of the group cadmium relative to the control, complete blood count demonstrated a very highly significant increase $(\mathrm{p}<0.001)$ in the white blood cell count, the hematocrit of the cadmium lot compared to the control, a very highly significant decrease $(\mathrm{p}<0.001)$. The red blood cell and hemoglobin levels of the cadmium group compared to the control. A significant improvement $(\mathrm{p}<0.001),(\mathrm{p}<0.01)$, and $(\mathrm{p}<0.05)$ of lots: Zinc, magnesium, cadmium + zinc, and cadmium + zinc compared to cadmium. However, the results obtained from the neurobehavioral tests reveal a significant elevation $(p<0.001)$, $(p<0.01)$, and $(p<0.05)$ in the number of cells crossed, the number of straightening in the test. Open field in the group exposed to cadmium resulting in locomotors hyperactivity compared to the control and it is minimal in other groups treated with zinc and magnesium. On the other hand, the plus maze (labyrinth test) revealed a very highly significant increase $(\mathrm{p}<0.001),(\mathrm{p}<0.01)$, and $(\mathrm{p}<0.05)$ of the time spent in the closed arms of the cadmium group compared to the control, a significant improvement ( $\mathrm{p}<0.001),(\mathrm{p}<0.01)$, and $(\mathrm{p}<0.05)$ of the lots: Zinc, magnesium, cadmium + zinc, and cadmium + zinc compared with cadmium.

Conclusion: Subchronic cadmium toxicity has harmful effects on the biochemical, hematological, and neuro-behavioral parameters of Wistar rats, with the installation of anxiety that will lead to a depressive state, which will be reduced and improved by the antioxidant effect of zinc + magnesium.

Keywords: Cadmium, Zinc, Magnesium, Wistar rats, Subchronic , Labyrinth test, Open field, Neurobehavioral.

(c) 2019 The Authors. Published by Innovare Academic Sciences Pvt Ltd. This is an open access article under the CC BY license (http://creativecommons. org/licenses/by/4. 0/) DOI: http://dx.doi.org/10.22159/ajpcr.2019.v12i5.29078

\section{INTRODUCTION}

Cadmium is a silvery white metal, is slightly bluish, is very malleable and ductile, is largely used in industrialized countries, is relatively rare, is not essential to the development of animal or plant organisms, and belongs to the family of transition metals [1,2]. On the other hand, its physical and chemical properties, close to those of zinc and calcium, allow it to cross biological barriers and accumulate in tissues. It is often associated with rocks with elements of the same group, such as zinc and mercury $[3,4]$

It is a contaminant found in the environment not only due to its natural presence on the earth's crust (in zinc ores, lead, and in the soil, and due to erosion) [5] but also and especially due to human activities such as the use of phosphate fertilizers in agriculture.

The main causes of human exposure to cadmium are diet (fish, bivalve mollusks, and vegetables of which vegetables rich in fiber) [6-8].

The interaction of cadmium with phosphate groups and heterocyclic bases nucleic acids suggests genetic abnormalities and disturbances of protein synthesis and carcinogenic effects $[9,10]$.
The interactions of cadmium with zinc may occur at different stages of the body's use of this micronutrient (absorption, distribution, and excretion) and this may affect the biological functions of zinc [11]. Zinc is an excellent antioxidant that prevents the synthesis of oxygen-free radicals that are responsible for oxidative stress $[12,13]$.

Many studies have shown that zinc supplementation can reduce the absorption and accumulation of cadmium at the tissue level and also prevent its harmful actions [14-16]

Studies have indicated that the use of elements such as zinc and magnesium prevents or reduces many toxic effects of cadmium on various organs and tissues such as the liver, kidneys, skeleton, and blood [17,18]. Magnesium is an essential cofactor for activating many enzyme systems in humans, involved in the metabolism of carbohydrates, lipids, proteins, and DNA, interacting directly with the substrate or the enzyme $[19,20]$.

In addition, magnesium alters the concentration of cadmium in the gastrointestinal tract by affecting intercellular leakage of cadmium from the intestinal lumen to the blood and consequently reduces its concentration $[21,22]$. 
Our study is based on the beneficial effect of zinc plus magnesium against subchronic cadmium exposure in Wistar rats by performing biochemical assays and neurobehavioral exploration through tests (Open field and plus maze)

\section{METHODS}

\section{Group distribution}

The experiment was carried out on 20 Wistar rats, weighing 180-232 g for an initial weight before starting treatment with cadmium. The rats are grouped in cages at a rate of five in groups. They are placed in a ventilated animal house, at a temperature of $21+1^{\circ} \mathrm{C}$ with artificial lighting that establishes a day/night cycle (day between 7 and $19 \mathrm{~h}$ ). Animal procedures were performed in accordance with the Ethics Committee of the National Research Center and followed the recommendations of the National Institutes of Health Guide for Care and Use of Laboratory Animals [23].

After an adaptation period of 15 days we started the experiments:

- Group (1) control was supplied only with tap water.

- Group (2) contaminated with cadmium (Cd): Water plus oral cadmium dose $15 \mathrm{mg} / \mathrm{kg} / \mathrm{l}$.

- Group (3) contaminated with (Cd) dose $15 \mathrm{mg} / \mathrm{kg} / \mathrm{l}$ in water plus magnesium $(\mathrm{Mg})$ dose $10 \mathrm{mg} / \mathrm{kg} / \mathrm{l}$ orally.

- Group (4) contaminated with (Cd) dose $15 \mathrm{mg} / \mathrm{kg} / \mathrm{l}$ in water plus zinc (Zn) dose $10 \mathrm{mg} / \mathrm{kg} / \mathrm{l}$ orally.

Administered doses

- $15 \mathrm{mg} / \mathrm{kg} / \mathrm{l}$ of cadmium chloride [24].

- $10 \mathrm{mg} / \mathrm{kg} / \mathrm{l}$ of zinc chloride [25].

- $10 \mathrm{mg} / \mathrm{kg} / \mathrm{l}$ of magnesium chloride [26]

The rats were poisoned with cadmium and treated with zinc plus magnesium for 45 days.

Signs of intoxication begin from 1 month of exposure.

\section{Biochemical assays}

Glucose assay

Glucose is converted by glucose oxidize into gluconic acid and peroxide of hydrogen $\left(\mathrm{H}_{2} \mathrm{O}_{2}\right)$. The latter, in the presence of peroxidase, oxidizes the chromogen colorless (4-aminophenazone) to a colored compound in red-violet [27].

Assay of alanine transferase (glutamic-pyruvic transaminase [GPT])

The principle is presented according to the following reaction:

Alanine + \pm- Cetoglutarate $\frac{3 / 4}{4} \frac{\mathrm{ALT}_{4} \mathrm{~T}}{B}$ Glutamate + Pyruvate

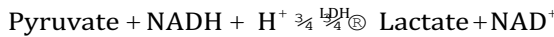

The decrease in NADH concentration is directly proportional to the activity the enzyme of alanine aminotransferase in the sample [27].

\section{Assay of aspartate aminotransferase (AST) (glutamic oxaloacetic} transaminase [GOT])

AST also known as GOT catalyzes the reversible transfer of an amino group from aspartate to $\alpha$-ketoglutarate forming glutamate and oxaloacetate. Oxaloacetate is reduced to malate by malate dehydrogenase and $\mathrm{NADH}, \mathrm{H}+[28]$

\section{Assay of urea}

Urease hydrolyzes urea to ammoniac ( $\mathrm{NH} 4+)$ and carbon dioxide $\left(\mathrm{CO}_{2}\right)$. The ammonium ion reacts with salicylate and hypochlorite in nitroprusside catalyzed reaction to give indophenol [29].

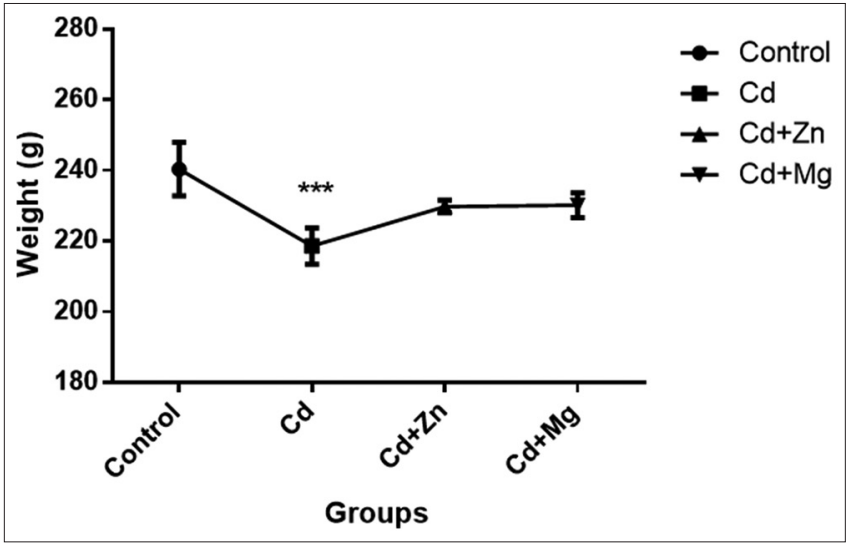

Fig. 1: Variation in body weight gain in control, Cd-contaminated, Zn-treated, Cd-contaminated, and Mg-treated and Cd-contaminated rats $(n=5)$. Values are expressed as mean $\pm S E M$ (*; $\left.\mathbf{p}<0.05^{* *} ; \mathbf{p}<0.011^{* *} ; \mathbf{p}<0.001\right)$

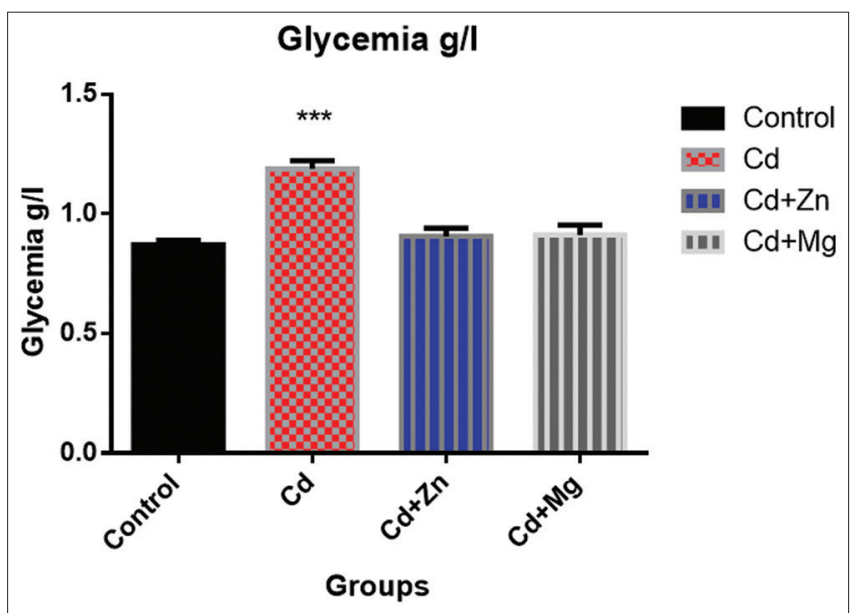

Fig. 2: Serum glucose concentration in control, Cd-contaminated, Zn-treated, Cd-contaminated, and Cd-contaminated rats $(\mathrm{n}=5)$. Values are expressed as mean $\pm \operatorname{SEM}(* ; \mathbf{p}<0.05 * * ; p<0.01$ $* * * ; \mathbf{p}<0.001$ )

\section{Assay of creatinine}

The test is based on the reaction of creatinine with picric acid: It is the reaction of JAFFE. Creatinine reacts with the alkaline picrate to give a colored complex, measured within a defined time interval and proportional to the creatinine concentration of the sample [30].

\section{Assessment of hematological toxicity}

The hematological toxicity was demonstrated by the determination of the digital blood formula (FNS) using an automatic Coulter. Measured parameters are red cells and white cells, hemoglobin $(\mathrm{Hb})$, and hematocrit (HCT).

\section{Neurobehavioral tests}

\section{Open field test}

Hall (1934) proposes the use of a locomotion index as an index of reactivity emotional seems problematic, especially during the first test session [31].

The device used is a plastic enclosure in the form of a $70 \mathrm{~cm}$ square and $30 \mathrm{~cm}$ high. It is divided into two parts: A peripheral part and a central part [32].

The locomotion in the open field was evaluated by raising the index of locomotion in the peripheral part as well as in the central part as 
a function of time. These two indices cumulative gives us the total locomotion index in the device [32].

The experimentation time lasts 5 minutes.

\section{Elevated plus maze (EPM) test}

The second device we chose to use is the plus maze test. In 1955, Montgomery described the rodents' aversion to empty spaces and height during the free exploration session from a familiar environment [33].

The device is cross-shaped and elevated to a height of $60 \mathrm{~cm}$ on the floor. He is consists of a central part $(10 \mathrm{~cm} \times 10 \mathrm{~cm})$, two open arms $(50 \mathrm{~cm} \times 10 \mathrm{~cm})$ without walls, and the other two arms are closed by walls $(50 \mathrm{~cm} \times 10$ $\mathrm{cm} \times 30 \mathrm{~cm}$ ) that are opposed two by two, the whole is made of wood. Opaque plastic edges with a height of $0.5 \mathrm{~cm}$ are attached to the open arms to facilitate entry [34] and to allow animals to grip in case of imbalance.

Given the aversion of rodents for empty spaces and height, the open arms of the device are more anxiety-provoking than the closed arms.

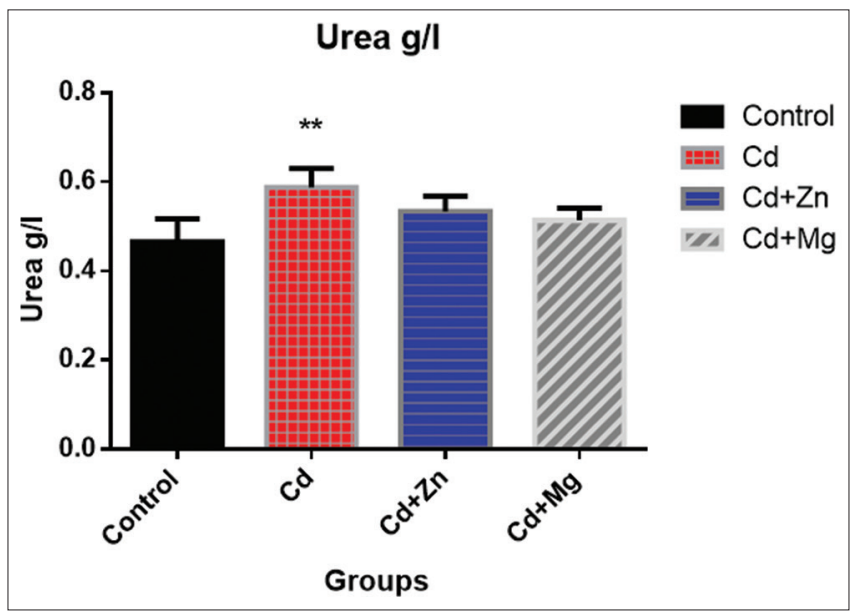

Fig. 3: Serum urea concentration in control, Cd-contaminated, Zn-treated, Md-contaminated, and Cd-contaminated rats $(n=5)$. Values are expressed as mean \pm SEM $\left(* ; p<0.05^{* *} ; \mathrm{p}<0.01\right.$ $* * * ; \mathbf{p}<0.001$ )

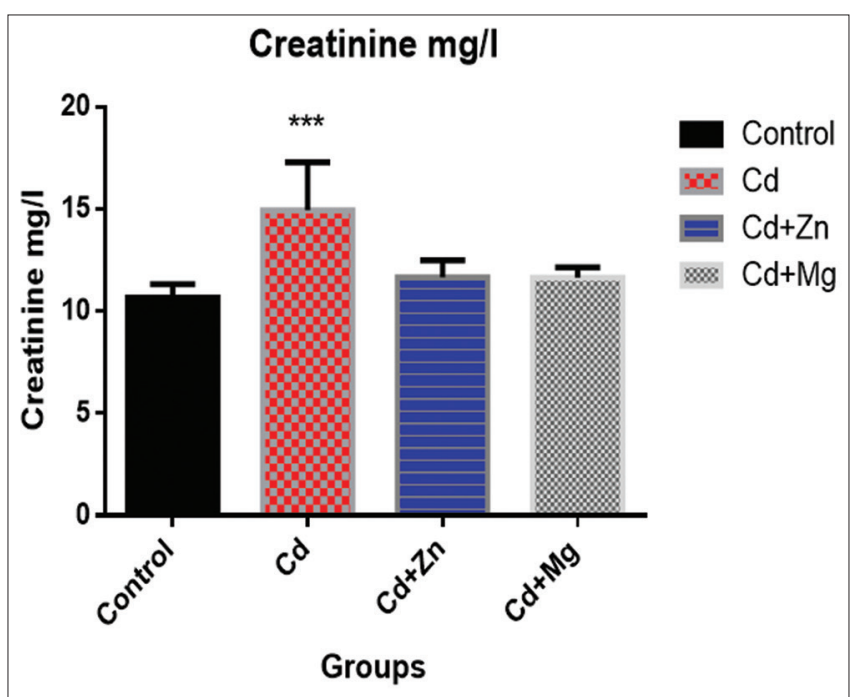

Fig. 4: Serum creatinine concentration in control, Cd-contaminated, Zn-treated, Md-contaminated, and Cd-contaminated rats $(n=5)$. Values are expressed as mean \pm SEM $\left(* ; \mathbf{p}<0.05^{* *} ; \mathbf{p}<0.01 * * * ; \mathbf{p}<0.001\right)$
Thus, the principle of the test is based on the conflict of approach/ avoidance of the open arms: An animal that explores the open arms will be described as being "not very anxious" and an animal that remains confined in the closed arms of the device will be described as being "Anxious" [32].

The test lasts $5 \mathrm{~min}$ and begins when the rat is placed in the center of the plus maze, facing an open arm to increase the latency of the first entry into an arm, but also the number of entry into the arm thereafter.

\section{Statistic study}

We used the GraphPad Prism 6 software and the one-way ANOVA variance test. $(\mathrm{p}<0.001),(\mathrm{p}<0.01)$, and $(\mathrm{p}<0.05)$ are considered significant.

\section{RESULTS}

\section{Effects on weight}

According to our results, the body weight of the rats was affected by $\mathrm{Cd}$; indeed, we notice a very highly significant decrease $(\mathrm{p}<0.001)$

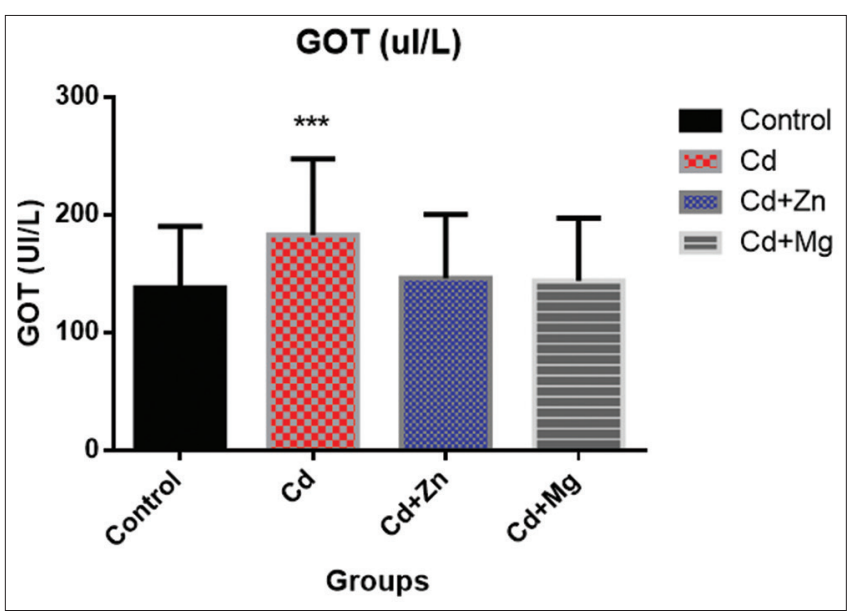

Fig. 5: The enzymatic activity of alanine aminotransferase (glutamic oxaloacetic transaminase) in control, Cd-contaminated, Zn-treated, Cd-contaminated, and Mg-treated and Cd-contaminated rats $(n=5)$. Values are expressed as mean \pm SEM $\left(* ; \mathbf{p}<0.05^{* *} ; \mathbf{p}<0.01 * * * ; \mathbf{p}<0.001\right)$

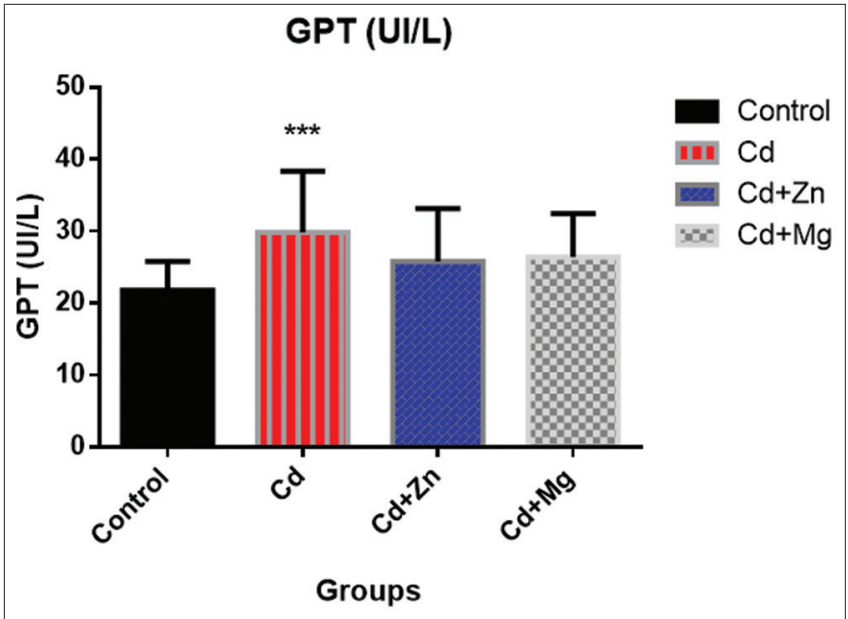

Fig. 6: The enzymatic activity of aspartate aminotransferase (TGP) in control, Cd-contaminated, Zn-treated, Cd-contaminated and Mg-treated and Cd-contaminated rats $(n=5)$. Values are expressed as mean \pm SEM $(* ; \mathbf{p}<0.05 * * ; \mathbf{p}<0.01 * * * ; \mathbf{p}<0.001)$ 
in body weight of Cd-contaminated rats compared to controls. While in Cd-contaminated rats treated with $\mathrm{Zn}$ and Cd-infected and Mg-treated rats, we do not notice a significant change in body weight compared to controls, which explains the beneficial effect of these two antioxidants ( $\mathrm{Zn}$ and $\mathrm{Mg}$ ). Against the oxidative stress caused by Cd.

\section{Effects on biochemical parameters}

Glycemia

Our results show a very highly significant $(\mathrm{p}<0.001)$ increase in serum glucose concentration in the Cd-contaminated lot compared with controls. While in Cd-contaminated rats treated with $\mathrm{Zn}$ and Cd-contaminated and Mg-treated rats, we do not notice a significant change in serum glucose concentration compared to controls (Fig. 2).

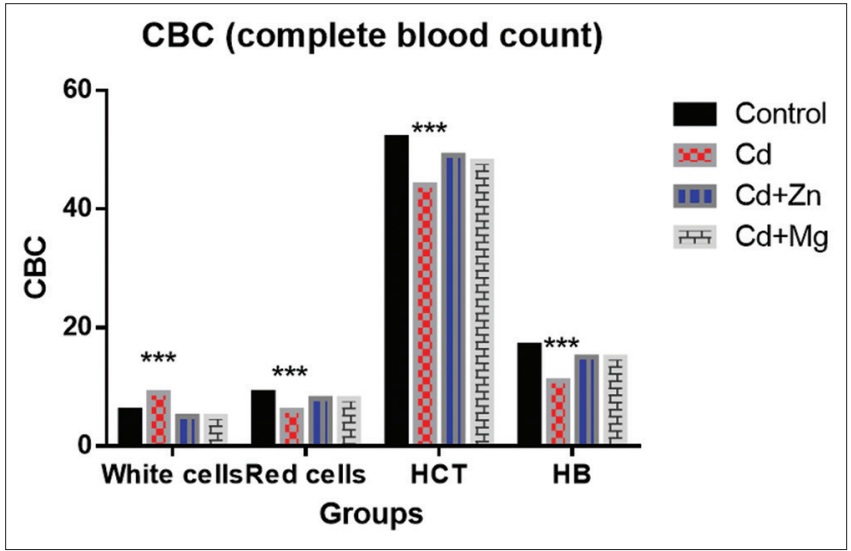

Fig. 7: Number of white blood cells, red blood cells, hematocrit, and hemoglobin levels in control, Cd-contaminated, Zn-treated, Cd-contaminated, Mg-treated, and Cd-contaminated rats $(n=5)$. Values are expressed as mean \pm SEM $\left(* ;\right.$ p $<0.05^{* *}$; p $<0.01 * * *$; $\mathrm{p}<0.001)$
Urea

Our results show a highly significant $(\mathrm{p}<0.01)$ increase in serum glucose concentration in the Cd-contaminated lot compared with controls. While in Cd-contaminated rats treated with $\mathrm{Zn}$ and Cd-infected and Mg-treated rats, we notice a decrease in serum urea concentration compared with Cd (Fig. 3).

\section{Creatinine}

Our results show a very highly significant $(\mathrm{p}<0.001)$ increase in serum creatinine concentration in the Cd-contaminated lot compared with controls. While in Cd-contaminated rats treated with $\mathrm{Zn}$ and Cdinfected and Mg-treated rats, we notice a decrease in serum creatinine compared with Cd (Fig. 4).

GOT

Regarding the enzymatic activity of alanine aminotransferase (GOT), the results reveal a very highly significant increase $(p<0.001)$ in the Cd-contaminated lot compared with controls. On the other hand, in Cd-contaminated rats treated with $\mathrm{Zn}$ and Cd-contaminated and Mg-treated rats, we observe a decrease in the enzymatic activity of alanine aminotransferase (GOT) compared with Cd.

\section{GPT}

Regarding the enzymatic activity of AST (GPT), the results obtained reveal a very highly significant increase $(\mathrm{p}<0.001)$ in the batch contaminated with Cd compared to controls. On the other hand, in Cd-contaminated rats treated with $\mathrm{Zn}$ and $\mathrm{Cd}$-contaminated and Mg-treated rats, we notice a decrease in enzymatic activity of AST (GPT) compared with Cd (Fig. 6).

\section{Effects on hematological parameters}

The results show a very highly significant increase $(\mathrm{p}<0.001)$ of white blood cells in a Cd-contaminated batch compared to the control group, whereas in $\mathrm{Cd}$-contaminated rats treated with $\mathrm{Zn}$ and $\mathrm{Cd}$-infected rats and treated with $\mathrm{Mg}$, we notice a decrease in white blood cell levels compared to $\mathrm{Cd}$ which confirms the beneficial effect of these two antioxidants ( $\mathrm{Zn}$ and $\mathrm{Mg}$ ) against the toxicity of Cd (Fig. 7).

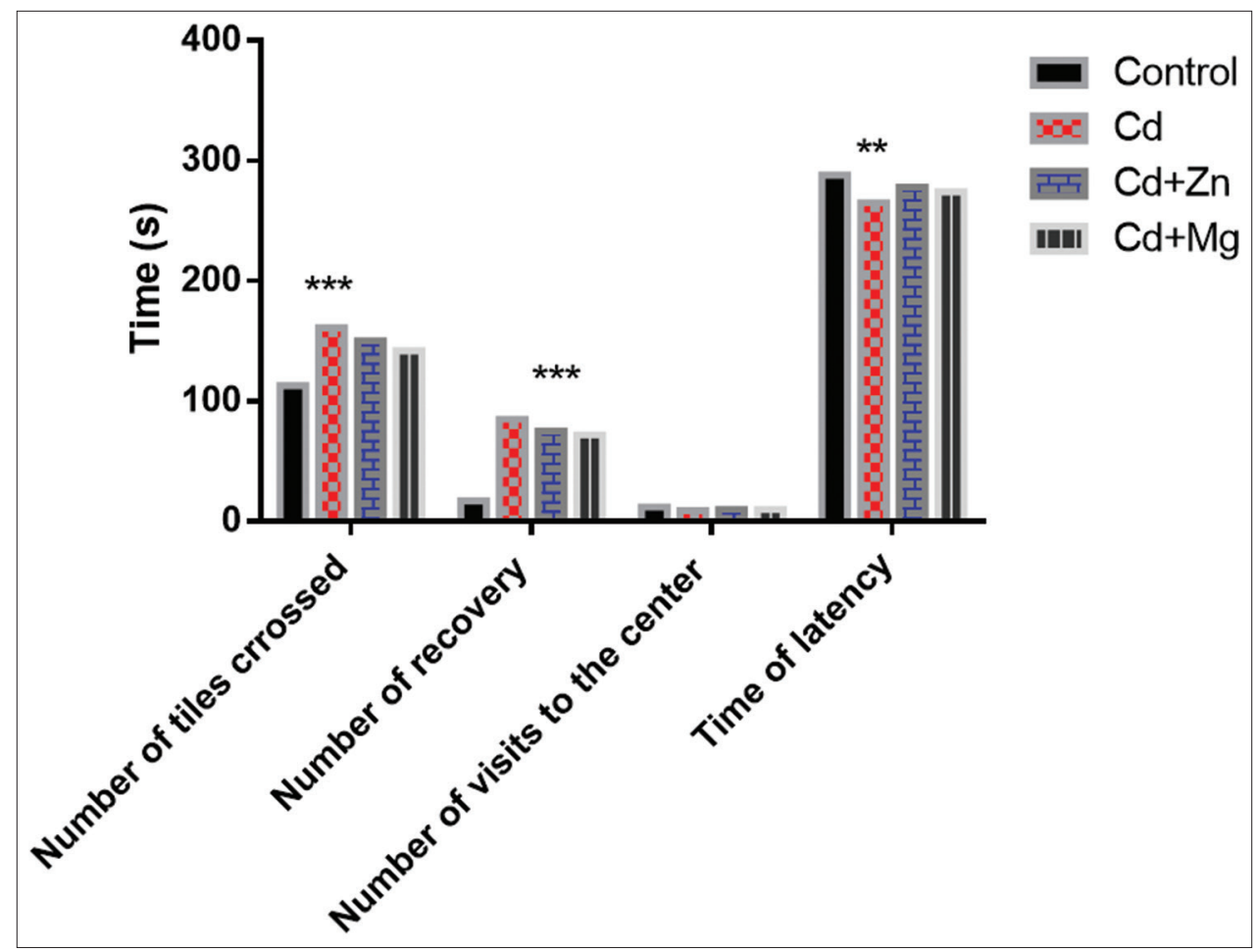

Fig. 8: Open field test in control, Cd-contaminated, Zn-treated, Cd-contaminated, and Cd-contaminated rats (n=5). Values are expressed as mean \pm SEM $(* ;$ p $<0.05 * * ; p<0.01 * * * ; p<0.001)$ 


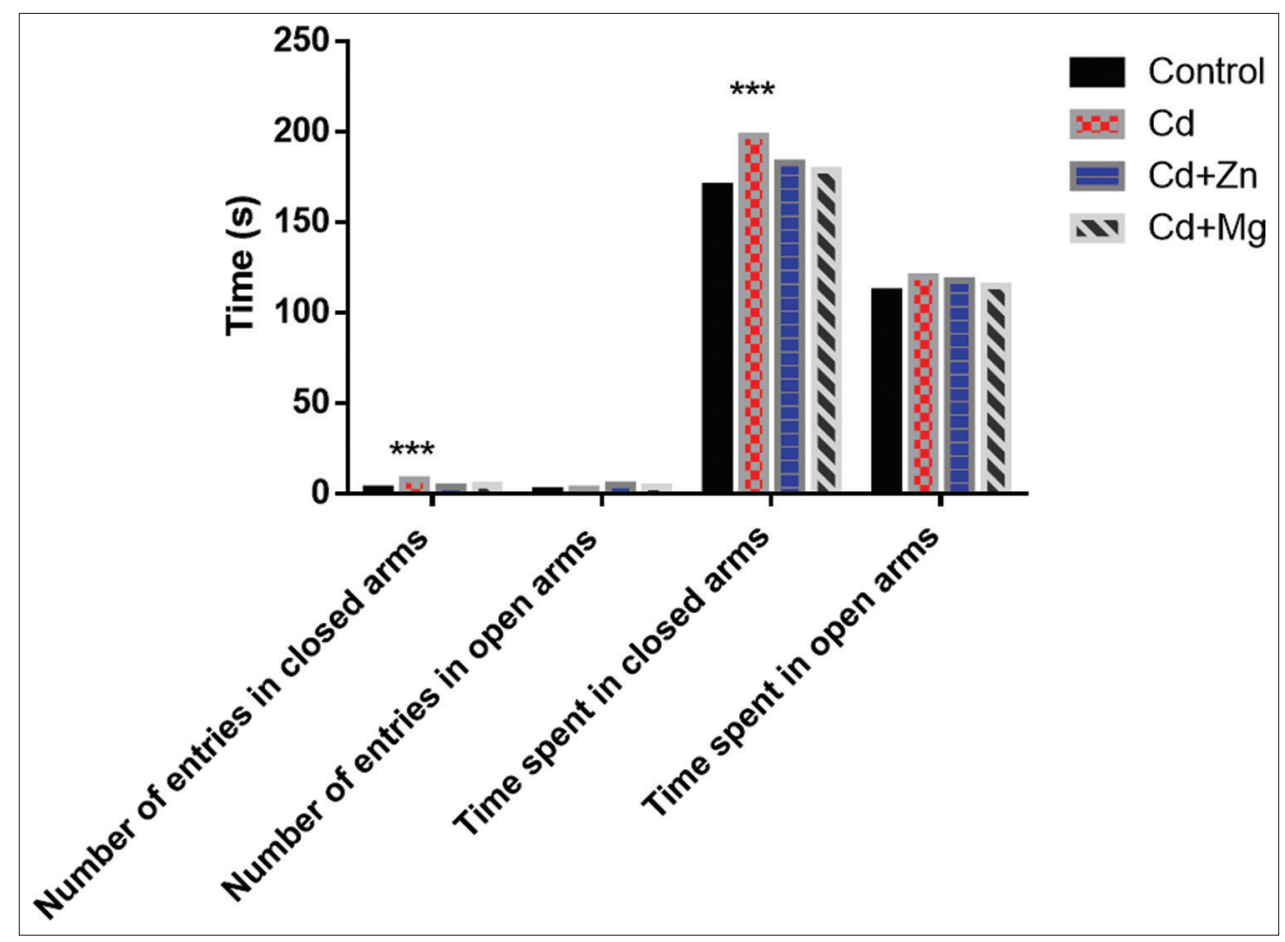

Fig. 9: The elevated plus maze test in control, Cd-contaminated, Zn-treated, Md-contaminated, and Cd-contaminated rats ( $\mathrm{n}=5$ ). Values are expressed as mean \pm SEM $\left({ }^{*} ; \mathbf{p}<0.05^{* *} ; \mathbf{p}<0.01{ }^{* * *} ; \mathbf{p}<0.001\right)$

Regarding the rate of red blood cells, we noticed a very highly significant decrease $(\mathrm{p}<0.001)$ in $\mathrm{Cd}$-contaminated batch compared to the control group, while in the Cd-contaminated rats treated with $\mathrm{Zn}$ and $\mathrm{Cd}$-contaminated rats and treated with $\mathrm{Mg}$, we notice an increase in the rate of red blood cells compared to $\mathrm{Cd}$ which confirms the beneficial effect of these two antioxidants $(\mathrm{Zn}$ and $\mathrm{Mg}$ ) against the toxicity of $\mathrm{Cd}$.

A very highly significant $(\mathrm{p}<0.001)$ decrease in HCT in the Cdcontaminated lot compared to the control group, whereas in $\mathrm{Cd}$ contaminated rats treated with $\mathrm{Zn}$ and Cd-contaminated rats and treated with $\mathrm{Mg}$, we notice an increase in HCT relative to $\mathrm{Cd}$ which confirms the beneficial effect of these two antioxidants ( $\mathrm{Zn}$ and $\mathrm{Mg}$ ) against the toxicity of $\mathrm{Cd}$.

A very highly significant $(\mathrm{p}<0.001)$ decrease in $\mathrm{Hb}$ in the Cd-contaminated lot compared to the control group, whereas in $\mathrm{Cd}$-contaminated rats treated with $\mathrm{Zn}$ and $\mathrm{Cd}$-contaminated rats and treated with $\mathrm{Mg}$, we notice an increase in $\mathrm{HCT}$ relative to $\mathrm{Cd}$ which confirms the beneficial effect of these two antioxidants ( $\mathrm{Zn}$ and $\mathrm{Mg}$ ) against the toxicity of $\mathrm{Cd}$.

\section{Effects on neurobehavioral parameters}

Open field test

The results of the open field test show a very highly significant increase $(p<0.001)$ in the number of cells crossed in the Cd-contaminated lot compared to the control group, whereas there is no significant change in the number of cells crossed. In Cd-contaminated rats treated with $\mathrm{Zn}$ and Md-treated and Mg-treated rats compared to controls.

A very highly significant increase $(\mathrm{p}<0.001)$ in the number of remedies in the Cd-contaminated lot compared with the control group, whereas there was no significant change in the number of cells crossed than in the Cd-contaminated rats treated with $\mathrm{Zn}$ and Cd-contaminated and Mg-treated rats compared to controls.

There was no significant change in the number of visits to the center in the Cd-contaminated lot compared to the control group, the same for the Cd-contaminated rats treated with $\mathrm{Zn}$ and the $\mathrm{Cd}$-contaminated and Mg-treated rats compared to the controls.

Finally, there is a highly significant $(\mathrm{p}<0.01)$ increase in the latency time in the Cd-contaminated batch compared to the control group, whereas there is no significant change in the number of cells crossed than in the $\mathrm{Cd}$-contaminated rats treated. $\mathrm{Zn}$ and $\mathrm{Cd}$-infected and Mg-treated rats compared to controls (Fig. 8).

\section{EPM}

Based on our results, there was a very highly significant $(p<0.001)$ increase in the number of closed arms entering the Cd-contaminated group compared with the control group. On the other hand, there was no significant change in the number of cells crossed than in the $\mathrm{Cd}$-contaminated rats treated with $\mathrm{Zn}$ and the Cd-contaminated and Mg-treated rats compared to the controls.

No significant change in the number of open arms entered in the Cd-contaminated lot compared to the control group, while there was no significant change in the number of open arms in Cd-treated and $\mathrm{Zn}$-treated rats and Md-treated and Mg-treated rats compared to controls.

There was also a very highly significant $(\mathrm{p}<0.001)$ increase in closed-arm time in the Cd-contaminated lot compared with the control group, but no significant change in closed-arm time in contaminated rats. $\mathrm{Cd}$ and treated with $\mathrm{Zn}$ and Cd-infected and Mg-treated rats compared to controls (Fig. 9).

\section{DISCUSSION}

Heavy metals all have a toxic potential which depends mainly on their concentration in the medium under consideration and their bioavailability, i.e., of their soluble and accessible function by organisms. Too high concentrations of even essential heavy metals are toxic to living organisms [35].

The bioavailability of heavy metals defines their ability to be transferred from one compartment to another, which increases the risk of toxicity to living organisms [36]. 
Among these heavy metals are cadmium (Cd), a toxic heavy metal and a major environmental pollutant found in soil, water, air, food, and cigarette smoke [37].

The objective of our study was to evaluate the impact of subchronic cadmium exposure on Wistar rats during a 45-day experimental period and to see the protective and beneficial effect of $(\mathrm{Zn}+\mathrm{Mg})$ against toxicity of cadmium.

Our experimental study demonstrated that subchronic exposure to cadmium (15 mg/kg/l) altered the body weight of Wistar rats, as we observed weight loss in cadmium-contaminated rats compared with controls.

This remarkable decrease is due to an increase in the degeneration of lipids and proteins caused by the toxicity of cadmium [38]. On the other hand, cadmium reacts with several nutrients [39]; divalent $\mathrm{Cd}+2$ metals affect the metabolism or tissue concentrations of several important components of mammalian bone metabolism: Calcium, magnesium, and zinc $[40,41]$; it can induce bad assimilation of food by the body $[42,43]$.

In contrast, the treatment of rats treated with zinc ( $\mathrm{Zn}$ ) and magnesium $(\mathrm{Mg})$ resulted in an improvement in body weight.

Our results show a high blood sugar level (serum glucose) in rats contaminated with cadmium. This hyperglycemia is caused by the toxicity of cadmium [44], which inhibits the production of insulin by islets of Langerhans [45], or it blocks the use of glucose by cells and leads to the presence of a high concentration of insulin [46] or due to disruption in glucagon secretion and leads to high degradation of glycogen, offers new glucose production from other non-carbohydrate sources such as proteins [44].

These results are consistent with $[44,46]$ studies in rats.

Treatment with zinc and magnesium will improve glucose levels in cadmium-contaminated rats and this suggests that zinc treatment will cause a decrease in the effect of cadmium by binding to biomolecules as well as improving insulin secretion by reducing glucose accumulation. Zinc protects enzymes and ATP involved in glucose metabolism $[47,48]$.

The increase in serum levels of urea and creatinine in cadmiumcontaminated rats is considered a biomarker of renal dysfunction and renal damage caused by this metal. Urea and creatinine are essential parameters for assessing renal function and glomerular filtration [49].

In addition, the increase of urea in the serum is correlated with the increase of protein catabolism; the proteins can be degraded into amino acids and then urea and creatinine.

Therefore, the increase in urea and creatinine in cadmium-contaminated rats is due to the nephrotoxic effect of cadmium $[50,51]$.

On the other hand, the administration of zinc to the cadmiumcontaminated group decreased with urea and creatinine compared to the cadmium lot, which is almost normal compared to controls, the same for zinc lot compared to controls.

Other authors have also conclusively proved that zinc stimulates the protein synthesis [52,53] which makes zinc an essential factor for protein synthesis.

Several studies have demonstrated the protective effect of magnesium against the toxic effects of cadmium [54]. This effect of magnesium could be explained by the competitive antagonism between cadmium and magnesium [55]. Matovic's work has shown that adding magnesium could reduce cadmium levels in the kidneys. [55].

Our results show an increase in the enzymatic activity of transaminases (GPT and GOT) in the serum of cadmium-contaminated rats. The increase in these enzymes indicates a hepatic injury and is explained by the leakage of enzymes from the tissue to the plasma due to the alteration of the membrane permeability [56].

These results are consistent with the work of Navarro et al. [57], Tandon et al. [58], Uyanik et al. [59] in rats that confirmed the increase of these enzymes.

Zinc treatment improved the activity of transaminase enzymes TGO, TGP in cadmium-contaminated rats. This antioxidant can stabilize the hepatic cell membrane and protect hepatocytes against the toxic effects of cadmium which can decrease enzyme leakage to plasma [60-63].

Magnesium treatment improved the activity of transaminase enzymes TGO, TGP in cadmium-contaminated rats. This antioxidant can stabilize the hepatic cell membrane and protect hepatocytes against the toxic effects of cadmium which can decrease enzyme leakage to plasma $[64,65]$.

Regarding the study of hematological parameters, the analysis of our results showed that the subchronic exposure of rats to cadmium caused a significant decrease in red blood cells, Hb, and HCT. From these results, it can be said that cadmium caused anemia [66].

This anemia is due, on the one hand, to the effects of free radicals generated by cadmium on red blood cells, where some free radicals such as $02 .-$ and $\mathrm{OH}$ are very species reagents causing cellular damage through peroxidation membrane lipids, moreover in the presence of high concentrations of these radicals, $\mathrm{Hb}$ can easily oxidize [67-69]. These results are in agreement with the studies $[70,71]$.

In contrast, there was a clear increase in white blood cells among cadmium contaminated rats compared to controls. This increase is explained by the fact that the animal mobilizes all these defense capacities (in particular, the leukocytes) to fight against the infectious agents caused by the presence of xenobiotics in its organism [72]. This confirms the importance of the globules white in immune defense against toxic elements.

However, this anemia is corrected in groups treated with $\mathrm{Cd}+\mathrm{Zn}$, $\mathrm{Cd}+\mathrm{Mg}$ after 45 days of treatment; which further demonstrates the cytotoxic effect of cadmium [73,74].

We have chosen a battery of neurobehavioral tests to assess the state of depression, anxiety, locomotor activity, and a blood glucose test since it is good indicator stress.

These tests were performed to estimate the state of stress in Wistar rats exposed to cadmium compared to controls.

Regarding the open field test, the results noted clearly show that oral administration of cadmium showed a very high increase significantly in the number of cells crossed and the number of recoveries, which reveals locomotor hyperactivity in poisoned rats compared to nonintoxicated rats.

This increase in exploration is explained by the action of heavy metals (cadmium) on the dopaminergic system which results in an increase in synthesis, release of the neurotransmitter, and hyperfunctioning postsynaptic receivers [75].

On the other hand, in lots treated with zinc and magnesium, we noticed a decrease in the number of cells crossed and the number of recoveries. This is due to the beneficial and antioxidant power of zinc and magnesium which are trace elements that enter the development of the nervous system and synaptic transmission signal $[15,76]$.

Furthermore, we examined the action of cadmium orally on Wistar rats during the most maze test; we noticed a very highly significant increase in the number of entries in the closed arms and the time spent in the 
closed arms. This is explained by the anxious and depressive state caused by cadmium in Wistar rats.

The plus maze test is one of the most popular behavior patterns for anxiety, the increase in the number of entries and the time spent in the open arms are considered to be the most representative indices of anxiolytic activity.

In this device, the rats prefer to spend much of their time in the closed arms; this behavior seems to reflect an aversion to open arms that are generated by the fear of open spaces. Drugs that increase open-arm exploration are considered anxiolytics and the opposite is true for anxiogens $[77,78]$.

Unlike the cadmium group, lots $\mathrm{Cd}+\mathrm{Zn}$ and $\mathrm{Cd}+\mathrm{Mg}$ show some improvement and decrease in the number of entries in the closed arms, the time spent in closed arms this is explained by the antioxidant capacities of zinc and magnesium to reduce the effect of cadmium on the nervous system by reinforcing dopaminergic and serotonergic transmission in Wistar rats $[13,15,79-80]$.

Finally, it is clear that when Cd-treated rats were subjected to $\mathrm{Zn}$ and/ or Mg supplementation, the $\mathrm{Zn}$ and $\mathrm{Mg}$ provides protection against $\mathrm{Cd}$ induced oxidative stress and toxicity in the liver and kidney tissues. It may be concluded that the mixture of $\mathrm{Zn}$ and $\mathrm{Mg}$ supplementation was more beneficial against subchronic toxicity of $\mathrm{Cd}[81,82]$.

\section{CONCLUSION}

The results obtained show that the subchronic toxicity to $\mathrm{Cd}$ is responsible for a disruption of the biochemical, hematological, and neurobehavioral parameters that can be summarized in the following points:

- The physiological study shows that the Cd-induced a weight deficit compared to the control, knowing that the administration of $\mathrm{Zn}$ and Mg improved the growth of the rats.

- A disruption of the biochemical metabolism, the Cd-induced an increase in the concentration of glucose, urea, and creatinine, this is accompanied by an increase in the enzymatic activity of the hepatic markers TGP and TGO, and these changes are corrected by the addition of $\mathrm{Zn}$ plus $\mathrm{Mg}$

- The hematological study shows a decrease in the number of red blood cells, Hb, and HCT with an increase in white blood cells in the batch contaminated with $\mathrm{Cd}$ compared to the control. Note that, these rates are improved after adding $\mathrm{Zn}$ plus Mg.

- The neurobehavioral study shows first according to the open field test that Cd contamination induces an increase in the number of cells crossed and the number of recoveries, as well as a decrease in the lag time compared to the control group. Note that, the addition of Zn plus Mg improved these parameters. On the other hand, and according to the plus maze test, the Cd has induced an increase in the number of entries and the time spent in the closed arms. These parameters are corrected by the administration of $\mathrm{Zn}$ plus Mg.

Finally, we can confirm that $\mathrm{Cd}$ has hepatotoxic, hematotoxic, and nephrotoxic effects, as well as effects on the nervous system, due to its impact on the metabolic function of the liver, on blood parameters, on renal function, and also on neurobehavioral parameters reflected by the presence of a depressive state and anxiety.

It should be noted that treatment with $\mathrm{Zn}$ plus Mg has fewer effects than those observed after contamination with $\mathrm{Cd}$ alone. Thus, it can be confirmed that the administration of $\mathrm{Zn}$ plus Mg reduced the toxicity of $\mathrm{Cd}$ as antioxidants against free radicals.

\section{ACKNOWLEDGMENT}

This research work is financially supported by the Ministry of Higher Education and scientific research of Algeria. We wish to acknowledge Pr. Abdelkrim Tahraoui Applied Neuroendocrinology Laboratory
Department of Biology University Badji Mokhtar Annaba Algeria for his help support and encouragement.

\section{AUTHOR'S CONTRIBUTIONS}

We declare that this work was done by the authors named in this article and all liabilities pertaining to claims relating to the content of this article will be borne by the authors. Dr. Samir Djemli collected and analyzed the data wrote and prepared the manuscript. Mr. Mohamed Kouadria conducted the experiment. Pr. Abdelkrim Tahraoui helped in the experiment.

\section{CONFLICTS OF INTEREST}

The authors declare that they have no conflicts of interest in relation to this article.

\section{REFERENCES}

1. Malayeri BE. Décontamination des Sols Contenant Des Métaux Lourds à L'aide de Plantes et de Microorganismes, These en Biologie des Organismes. France, Nancy: Université Henri Poincaré; 1995. p. 6-8.

2. Martineau C. Caractérisation de la Cytotoxicité et de L'accumulation du Cadmium Dans Différentes Lignées Ostéoblastiques Humaines et Murjnes. Montréal: Université du Québec à Montréal; 2008. p. 11-15.

3. Zorrig W. Recherche et Caractérisation de Déterminants Contrôlant L'accumulation de Cadmium Chez la Laitue Lactuca sativa, Thèse Doctorat en Physiologie Végétale et Biologie Moléculaire. Tunisia: Université Tunis El Manar; 2010. p. 24-9.

4. Chiffoleau JF, Gonzalez JL, Miramand P, Thouvenin B. Le Cadmium: Comportement d'un Contaminant Métallique en Estuaire. Programme Scientifique Seine Aval; 1999. p. 31.

5. Das P, Samantaray S, Rout GR. Studies on cadmium toxicity in plants: A review. Environ Pollut 1997;98:29-36.

6. Rousselet E. Réponse Cellulaire vis-a-vis de L'exposition au Cadmium Chez les Animaux, Thèse Doctorat en Biologie. France: Université Joseph Fourier-Grenoble; 2007. p. 19-72.

7. ATSDR. Draft Toxicological Profile for Cadmium. In ATSDR. Atlanta (GA): Agency for Toxic Substances and Disease Registry; 2008.

8. Bisson M, Houeix N. Cadmium et Ses Dérivés, INERIS Fiche de Données Toxicologiques et Environnementales des Substances Chimiques; 2014. Available from: http://www.fmichele.bisson@ineris.fr.

9. Baptiste PJ. Les Plans de Surveillance et de Contrôle Dans L'analyse du Risque Alimentaire lié Aux Métaux Lourds en France. Thèse Doctorat en Sciences Vétérinaire; 2007.

10. Stoll RE, White JF, Miya TS, Bousquet WF. Effects of cadmium on nucleic acid and protein synthesis in rat liver. Toxicol Appl Pharmacol 1976;37:61-74.

11. Lansdown AB, Sampson B, Rowe A. Experimental observations in the rat on the influence of cadmium on skin wound repair. Int J Exp Pathol 2001;82:35-41.

12. Fernandez E, Gustafson A, Anderson M, Hellman B, Dencker L. Cadmium induced changes in apoptic gene expression blocked by zinc supplementation. Toxicol Sci 2003;10:85-99.

13. Santon A, Irato P, Medici V, D'Incà R, Albergoni V, Sturniolo GC, et al. Effect and possible role of $\mathrm{Zn}$ treatment in LEC rats, an animal model of Wilson's disease. Biochim Biophys Acta 2003;1637:91-7.

14. Tandon SK, Singh S, Prasad S, Mathur N. Hepatic and renal metallothionein induction by an oral equimolar dose of zinc, cadmium or mercury in mice. Food Chem Toxicol 2001;39:571-7.

15. Brzóska MM, Moniuszko-Jakoniuk J. Interactions between cadmium and zinc in the organism. Food Chem Toxicol 2001;39:967-80.

16. Liu J, Qu W, Kadiiska MB. Role of oxidative stress in cadmium toxicity and carcinogenesis. Toxicol Appl Pharmacol 2009;238:209-14.

17. Merali Z, Singhal RL. Prevention by zinc of cadmium-induced alterations in pancreatic and hepatic functions. $\mathrm{Br} \mathrm{J}$ Pharmacol 1976;57:573-9.

18. Rogalska J, Brzóska MM, Roszczenko A, Moniuszko-Jakoniuk J. Enhanced zinc consumption prevents cadmium-induced alterations in lipid metabolism in male rats. Chem Biol Interact 2009; 177:142-52.

19. Shaikh ZA, Tang W, Sadovic S. Zinc-Induced Protection Against Cadmium Metallothionein Nephrotoxicity Depends on Glutathione Status. Metallothionein IV. New York: Springer; 1999. p. 467-9.

20. Xiao P, Jia XD, Zhong WJ, Jin XP, Nordberg G. Restorative effects of zinc and selenium on cadmium-induced kidney oxidative damage in rats. Biomed Environ Sci 2002; 15:67-74. 
21. Chowdhury BA, Friel JK, Chandra RK. Cadmium-induced immunopathology is prevented by zinc administration in mice. J Nutr 1987; $117: 1788-94$

22. Zhang D, Gao J, Zhang K, Liu X, Li J. Effects of chronic cadmium poisoning on $\mathrm{Zn}, \mathrm{Cu}, \mathrm{Fe}, \mathrm{Ca}$, and metallothionein in liver and kidney of rats. Biol Trace Elem Res 2012;149:57-63.

23. NIH Guide for the Care and Use of Laboratory Animals: (a) DHEW 452 Publication No. (NIH) 8-23, Revised 1978 and (b) NIH Publication No.453-85-23, Revised. United States: US Department of Health, Educations and Welfare; 1985. p. 454.

24. Alvarez SM, Gómez NN, Scardapane L, Zirulnik F, Martínez D, Giménez MS, et al. Morphological changes and oxidative stress in rat prostate exposed to a non-carcinogenic dose of cadmium. Toxicol Lett 2004; $153: 365-76$.

25. El Din Omar H, Ibrahim A, Magdy M, Ahmed E. The protective effects of zinc and Vitamin E supplementation against kidney toxicity by lithium in rats. Eur J Biol Res 2016;6:21-7.

26. Soltani N, Keshavarz M, Sohanaki H, Dehpour AR, Zahedi Asl S. Oral magnesium administration prevents vascular complications in STZdiabetic rats. Life Sci 2005;76:1455-64.

27. Kaplan A, Glucose K. Clinical Chemistry. Toronto, Princeton: The CV Mosby Co.; 1984. p. 1032-6.

28. Murry R. Aspartate aminotransferase. Clinical Chemistry. Toronto, Princeton: The CV Mosby Co.; 1984. p. 1112-6.

29. Kaplan, A. Urea. Clinical Chemistry. Toronto, Princeton: The CV Mosby Co.; 1984. p. 1257-60.

30. Murry RL. Creatinine. Clinical Chemistry. Toronto, Princeton: The CV Mosby Co.; 1984. p. 1261-6.

31. Soubrié. D. Open-Field chez le rat: Inter-relations entre locomotion exploration et emotivité. J Pharmacol 1971;2:457-72.

32. Roy V. Contribution à L'étude de Conduites Emotionnelles chez le rat: Utilisation du Handling Postnatal et de L'approche Ethoexpérimental du Comportement, Thèse de Doctorat. France: Université de Rouen; 2002.

33. Montgomery KC. The relation between fear induced by novel stimulation and exploratory behavior. J Comp Physiol Psychol 1955;48:254-60.

34. Treit D, Menard J, Royan C. Anxiogenic stimuli in the elevated plusmaze. Pharmacol Biochem Behav 1993;44:463-9.

35. Crine M. Le Traitement des Eaux Usées Industrielles Chargées en Métaux Lourds. Situation Actuelle et Perspectives de Développement, Tribune de L'eau; 1995.

36. Maynaud. Adaptation Aux Métaux Lourds de Populations de Rhizobia Impliquées Dans la Phytostabilisation de Déblais Miniers: Identification des Mécanismes D'adaptation au $\mathrm{Zn}$ et au Cd, et Structuration des Populations de Rhizobia Adaptées au Site Miniers. Thèse Doctorat Université de Montpellier; 2012.

37. World Health Organization. Environmental Health Criteria, 134Cadmium. Geneva: IPCS, World Health Organization; 1992.

38. Erdogan Z, Erdogan S, Celik S, Unlu A. Effects of ascorbic acid on cadmium-induced oxidative stress and performance of broilers. Biol Trace Elem Res 2005;104:19-32.

39. Solomons NW, Viteri F, Shuler TR, Nielsen FH. Bioavailability of nickel in man: Effects of foods and chemically-defined dietary constituents on the absorption of inorganic nickel. J Nutr 1982;112:39-50.

40. Sugawara N. Inhibitory effect of cadmium on calcium absorption from the rat duodenum. Arch Environ Contam Toxicol 1977;5:167-75.

41. Washko PW, Cousins RJ. Metabolism of Cd109 in rats fed normal and low-calcium diets. Toxicol Environ Health 1977;1:1056-66.

42. Nielsen FH, Shuler TR, McLeod TG, Zimmerman TJ. Nickel influences iron metabolism through physiologic, pharmacologic and toxicologic mechanisms in the rat. J Nutr 1984;114:1280-8.

43. Smialowicz RJ, Rogers RR, Riddle MM, Luebke RW, Fogelson LD, Rowe DG, et al. Effects of manganese, calcium, magnesium, and zinc on nickel-induced suppression of murine natural killer cell activity. J Toxicol Environ Health 1987;20:67-80.

44. Massanyi P, Toman R, Valent M, Cupka P. Evaluation of selected parameters of a metabolic profile and levels of cadmium in reproductive organs of rabbits after an experimental administration. Acta Physiol Hung 1995;83:267-73.

45. Dormer RL, Kerbey AL, McPherson M, Manley S, Ashcroft SJ, Schofield JG, et al. The effect of nickel on secretory systems. Studies on the release of amylase, insulin and growth hormone. Biochem J 1974; 140:135-42.

46. Sunderman FW Jr., Kasprzak K, Horak E, Gitlitz P, Onkelinx C. Effects of triethylenetetramine upon the metabolism and toxicity of $63 \mathrm{NiCl} 2$ in rats. Toxicol Appl Pharmacol 1976;38:177-88.
47. Rana SV, Singh R, Verma S. Protective effects of few antioxidants on liver function in rats treated with cadmium and mercury. Indian J Exp Biol 1996;34:177-9.

48. Noël L, Huynh-Delerme C, Guérin T, Huet H, Frémy JM, KolfClauw $\mathrm{M}$, et al. Cadmium accumulation and interactions with zinc, copper, and manganese, analysed by ICP-MS in a long-term caco-2 TC7 cell model. Biometals 2006;19:473-81.

49. Ambali SF, Shuaib K, Edeh R, Orieji BC, Shittu M, Akande M. Hyperglycemia induced by subchronic co-administration of chlorpyrifos and lead in Wistar rats: Role of pancreatic lipoperoxidation and alleviating effect of Vitamin C. Biol Med 2011;3:6-14.

50. Finco DR, Kamekeo JJ, Harvey JW, BruceML. Kideny Fonctions in Clinical Biochemestiry of Domestic Animals. San Diego, California: Academic Press; 1997. p. 462-78.

51. Harper HA, Rodwell VW, Mayes PA, Cochrum KC, Grodsky GM, Martin DW, et al. Review of Physiological Chemistry. $17^{\text {th }}$ ed. Los Altos, California: Lange Medical Publications; 1979. p. 702

52. El-Demerdash FM, Yousef MI, Radwan FM. Ameliorating effect of curcumin on sodium arsenite-induced oxidative damage and lipid peroxidation in different rat organs. Food Chem Toxicol 2009;47:249-54.

53. Giugliano R, Millward DJ. The effects of severe zinc deficiency on protein turnover in muscle and thymus. Br J Nutr 1987; 57:139-55.

54. Ehara Y, Yamaguchi M. Zinc stimulates protein synthesis in the femoral-metaphyseal tissues of normal and skeletally unloaded rats. Res Exp Med (Berl) 1997;196:363-72.

55. Soldatovic D, Vujanovic D, Matovic V, Plamenac Z. Compared effects of high oral mg supplements and of EDTA chelating agent on chronic lead intoxication in rabbits. Magnes Res 1997;10:127-33.

56. Matović V, Buha A, Bulat Z, Dukić-Ćosić D. Cadmium toxicity revisited: Focus on oxidative stress induction and interactions with zinc and magnesium. Arh Hig Rada Toksikol 2011;62:65-76.

57. Navarro MC, Montilla MP, Martín A, Jiménez J, Utrilla MP. Free radical scavenger and antihepatotoxic activity of Rosmarinus tomentosus. Planta Med 1993;59:312-4

58. Tandon SK, Klandwal S, Jain VK, Marthur N. Influence of dietary iron deficiency on acute metal intoxication. Ind Toxicol Res Cent Biometals 1993;6:133-8

59. Uyanik F, Eren M, Atasever A, Tuncoku G, Kolsuz AH. Changes in some biochemical parameters and organs of broilers exposed to cadmium and effect of Zinc on cadmium induced alteration. Isr Vet Med 2001;56:128-34.

60. Pari L, Murugavel P. Role of diallyl tetrasulfide in ameliorating the cadmium induced biochemical changes in rats. Environ Toxicol Pharmacol 2005;20:493-500.

61. Bettger WJ, O'Dell BL. A critical physiological role of zinc in the structure and function of biomembranes. Life Sci 1981;28:1425-38

62. Waalkes MP, Kasprzak KS, Oshima M, Poirier LA. Protective effects of zinc acetate towards the toxicity of nickelous acetate in rats. Toxicology 1985;39:29-41.

63. Dhawan D, Goel A, Gautam CS. Effects of zinc intake on liver enzymes in carbon tetrachloride induced liver injury. Med Sci Res 1992;20:55-6.

64. Samir D, Kechrid Z, Djabar MR. Combined protective effect of zinc and Vitamin $\mathrm{C}$ on nickel-induced oxidative liver injury in rats. Sch Res Libr 2012;3:3410-8

65. Matovic V, Bulat ZP, Dukic-cosic D, Soldatovic D. Zinc, Copper, or Magnesium Supplementation Against Cadmium Toxicity. New York: Nova Science Pub Inc.; 2004.

66. Djukić-Cosić D, Ninković M, Malicević Z, Matović V, Soldatović D. Effect of magnesium pretreatment on reduced glutathione levels in tissues of mice exposed to acute and subacute cadmium intoxication: A time course study. Magnes Res 2007;20:177-86.

67. Kostić MM, Ognjanović B, Dimitrijević S, Zikić RV, Stajn A, Rosić GL, et al. Cadmium-induced changes of antioxidant and metabolic status in red blood cells of rats: In vivo effects. Eur J Haematol 1993;51:86-92.

68. Gürer H, Ozgünes H, Neal R, Spitz DR, Erçal N. Antioxidant effects of $\mathrm{N}$-acetylcysteine and succimer in red blood cells from lead-exposed rats. Toxicology 1998;128:181-9.

69. Hughes MF. Arsenic toxicity and potential mechanisms of action. Toxicol Lett 2002;133:1-6.

70. Modi M, Kaul RK, Kannan GM, Flora SJ. Co-administration of zinc and n-acetylcysteine prevents arsenic-induced tissue oxidative stress in male rats. J Trace Elem Med Biol 2006;20:197-204.

71. Tung HT, Cook FW, Wyatt RD, Hamilton PB. The anemia caused by aflatoxin. Poult Sci 1975;54:1962-9.

72. Yousef MI, Ibrahim HZ, Yacout HM, Hassan AA. Effects of cypermethrin and dimethoate on some physiological and biochemical 
parameters in Barki sheep. Egypt J Nutr Feeds 1998;1:41-52.

73. Karmakar R, Bhattacharya R, Chatterjee M. Biochemical, haematological and histopathological study in relation to time-related cadmiuminduced hepatotoxicity in mice. Biometals 2000;13:231-9.

74. Levander OA. Metabolic interrelationships between arsenic and selenium. Environ Health Perspect 1977;19:159-64.

75. Dogra S, Khanna AK, Kaw JL. Antibody forming cell response to nickel and nickel-coated fly ash in rats. Hum Exp Toxicol 1999;18:333-7.

76. Slotkin TA, MacKillop EA, Ryde IT, Tate CA, Seidler FJ. Screening for developmental neurotoxicity using PC12 cells: Comparisons of organophosphates with a carbamate, an organochlorine, and divalent nickel. Environ Health Perspect 2007;115:93-101.

77. Cernak I, Savic V, Kotur J, Prokic V, Kuljic B, Grbovic D, et al. Alterations in magnesium and oxidative status during chronic emotional stress. Magnes Res 2000;13:29-36.

78. Nic Dhonnchadha BA, Bourin M, Hascoët M. Anxiolytic-like effects of 5-HT2 ligands on three mouse models of anxiety. Behav Brain Res 2003;140:203-14.

79. Samir D, Asma F, Hacene F, Rachedi BA, Moncef Z, Réda D. Neurobehavioral effects of dexamethasone (inhibition of adrenal axis) in male mice Mus musculus. Glob Vet 2015; 15:545-53.

80. Golf SW, Bender S, Grüttner J. On the significance of magnesium in extreme physical stress. Cardiovasc Drugs Ther 1998;12 Suppl 2:197-202.

81. Jamakala AO, Rani U. Mitigating role of Zinc and Iron against Cadmium induced toxicityr liver and kidney of male albino Wistar: A study wiht reference to metallothioneine quantification. Int J Pharm Pharm Sci 2014;6:411-7.

82. Ige SF, Akhigbe RE, Edeogho O, Ajao FO, Owolabi OQ, Oyekunle OS, et al. Hepatoprotective activities of Allium cepa in cadmium-treated rats. Int J Pharm Pharm Sci 2011;3:60-3. 